\title{
PENGARUH MODEL PEMBELAJARAN KOOPERATIF TIPE TPS TERHADAP HASIL BELAJAR TEKNIK DASAR PASSING DAN CONTROL SEPAKBOLA
}

\author{
Ahmad Dahlan', I Putu Darmayasa², I Md. Satyawan³ \\ Jurusan Pendidikan Jasmani Kesehatan dan Rekreasi \\ Fakultas Olahraga dan Kesehatan Universitas Pendidikan Ganesha, \\ Kampus Tengah Undiksha Singaraja, Jalan Udayana Singaraja-Bali Tlp. (0362) 32559 \\ e-mail: alantengawoha@gmail.com¹, iputudarmayasa39@gmail.com², \\ anduksatya@yahoo.com\}@undiksha.ac.id ${ }^{3}$
}

\begin{abstract}
Abstrak
Penelitian ini bertujuan mengetahui pengaruh model pembelajaran kooperatif tipe Think Pair Share (TPS) terhadap hasil belajar teknik dasar passing dan control sepak bola. Penelitian ini adalah penelitian eksperimen sungguhan dengan menggunakan rancangan penelitian the randomized pretests-postest control group the same subject design. Subjek penelitian adalah siswa kelas XI SMA Saraswati Seririt Tahun Pelajaran 2017/2018 berjumlah 141 orang yang terdistribusi ke dalam empat kelas yaitu kelas XI IPA, XI IPS 1 sampai dengan kelas XI IPS 3. Pengundian kelompok eksperimen dan kelompok kontrol dilakukan dengan simple random sampling berdasarkan kelas. Data hasil belajar dikumpulkan melalui tes pilihan ganda, observasi dan unjuk kerja. Analisis data menggunakan Uji-t dengan bantuan SPSS 16.0 for Windows. Berdasarkan hasil penelitian ditemukan bahwa terdapat perbedaan hasil belajar teknik dasar passsing dan control sepakbola (kaki bagian dalam) antara siswa yang diberi perlakuan dengan model pembelajaran kooperatif tipe TPS dengan siswa yang diberi perlakuan model pembelajaran konvensional. Pada kelompok eksperimen diperoleh nilai rata-rata 0.4156 dengan standar deviasi 0.19195 Sedangkan pada kelompok kontrol diperoleh nilai rata-rata 0.3265 . dengan standar deviasi 0.15435 . Angka signifikansi yang diperoleh melalui Uji t adalah 0.023 dan $0.024<0.05$. Dengan demikian dapat disimpulkan bahwa model pembelajaran kooperatif tipe TPS berpengaruh positif terhadap hasil belajar teknik dasar passsing dan control sepakbola (kaki bagian dalam) pada siswa kelas XI SMA Saraswati Seririt Pelajaran 2017/2018. Model pembelajaran ini dapat dijadikan salah satu alternatif pembelajaran yang dapat diterapkan di kelas. Diharapkan peneliti lain untuk mencoba pada pokok bahasan lain untuk mengetahui pengaruh model pembelajaran kooperatif tipe TPS lebih mendalam.
\end{abstract}

Kata-kata kunci: Kooperatif, TPS, hasil belajar, sepakbola.

\begin{abstract}
This study aims to determine the effect of Think Pair Share (TPS) type of cooperative learning model on the learning outcomes of basic techniques of passing and control of football. This research is a real experiment used the randomized pretests-posttest control group the same subject design. The research subjects were students of class XI of Saraswati Seririt High School 2017/2018 Academic Year totaling 141 peoples who were distributed into four classes, namely class XI IPA, XI IPS 1 up to class XI IPS 3. The draw of the experimental group and the control group is done by simple random sampling based on the class. Learning outcomes data are collected through multiple choice tests, observations and performance. Data analysis used the T-Test with the help of SPSS 16.0 for Windows. Based on the results of the study it was found that there were differences in the learning outcomes of basic passing and control football techniques (inner foot) between students treated with TPS type cooperative learning models and students treated with conventional learning models. In the experimental group obtained an average value of 0.4156 with a standard deviation of 0.19195 while in the control group obtained an average value of 0.3265 . With a standard deviation of 0.15435 . The significance value obtained through T-Test are 0.023 and $0.024<0.05$. It can be concluded that cooperative learning model TPS has a positive effect on learning outcomes and control passing basic techniques of football students of class XI of Saraswati Seririt High School in 2017/2018 Academic. This learning model can be used as an alternative learning that can be applied in class. It is expected that other researchers will try on other subjects to find out the effect of applying the TPS type cooperative learning model more deeply.
\end{abstract}

Key words: Cooperative, TPS, learning outcomes, football. 


\section{PENDAHULUAN}

Proses pembelajaran merupakan kegiatan di mana terjadi penyampaian materi pembelajaran dari seorang tenaga pendidik kepada para peserta didik. Karenanya kegiatan pembelajaran ini sangat bergantung pada komponenkomponen yang ada di dalamnya. Dari sekian banyak komponen tersebut maka yang paling utama adalah adanya peserta didik, tenaga pendidik, media pembelajaran, materi pembelajaran serta adanya rencana pembelajaran dan model pembelajaran yang inovatif. Keberadaan komponen tersebut dalam sebuah proses pembelajaran merupakan sebuah hal yang teramat penting karena komponen tersebut sangat bergantung satu sama lain. Misalkan tentang adanya tenaga pendidik yang berkualitas.

Proses pembelajaran merupakan inti dari kegiatan pendidikan di sekolah khususnya dalam pembelajaran pendidikan jasmani olahraga dan kesehatan (penjasorkes). Pembelajaran penjasorkes bertujuan untuk membantu siswa dalam usaha meningkatkan derajat kesehatan dan kebugaran jasmani melalui keterampilan gerak dasar dalam berbagai aktivitas jasmani. Dengan demikian dalam kegiatan sehari-harinya, guru penjasorkes selalu bersentuhan dengan aktivitas gerak fisik. Aktivitas fisik tersebut akan tampak dalam aktivitas gerak siswa saat melakukan tugas-tugas gerak dalam proses pembelajaran, sehingga peranan guru dalam proses pembelajaran penjasorkes sangat menentukan keberhasilan proses pembelajaran.

Untuk meningkatkan hasil belajar siswa, perlu dilakukan peningkatan kualitas pembelajaran. "Upaya meningkatkan kualitas pembelajaran sangat dipengaruhi oleh faktor siswa, alat pendukung terjadinya pembelajaran, dan lingkungan" (Subadi:2011). Alat pendukung pembelajaran meliputi guru, kurikulum, sarana dan prasarana. Guru merupakan alat pendukung pembelajaran karena guru bertugas mempersiapkan dan mengelola pembelajaran. Dalam hal ini guru diharapkan dapat menyiapkan model pembelajaran dengan baik dan tepat sehingga peserta didik lebih mudah membangun pemahamannya sendiri. Hal ini menunjukkan bahwa model pembelajaran yang dipilih berpengaruh pada hasil belajar siswa. Siswa diharapkan dapat berperan penuh dalam proses pembelajaran dengan guru sebagai fasilitator.

Berdasarkan data satu tahun terakhir yang peneliti peroleh dari guru penjasorkes kelas XI SMA Saraswati Seririt mengenai proses pembelajaran penjasorkes materi passing dan control sepakbola berupa hasil belajar, bahwa nilai hasil ulangan harian materi bola besar (sepakbola) kelas XI masih banyak ditemukan siswa yang belum memenuhi Kreteria Ketuntasan Minimal (KKM). Dari total 141 siswa kelas $\mathrm{XI}$, hanya 50 orang (35\%) memperoleh nilai 73-90, 91 orang (65\%) memperoleh nilai $60-72$ dan tidak ada siswa (0\%) memperoleh nilai 0-60. Dengan rentangan KKM yang berlaku di kelas XI SMA Sarasawati Seririt khususnya pada mata pelajaran penjasorkes yang harus dicapai siswa adalah 73. Pada kelas XI IPA siswa berjumlah 34 orang, 21 orang yang memperoleh nilai 60-72, 13 orang memperoleh nilai 73-90, Siswa kelas XI IPS 1 berjumlah 36 orang, 25 orang siswa memperoleh nilai $60-72,11$ orang siswa memperoleh nilai 73-90, pada kelas XI IPS 2 dengan jumlah siswa 35 orang, 26 orang siswa memperoleh nilai 60-72, 9 orang memperoleh nilai 73-90, Kelas XI IPS 3 yang berjumlah 36 orang, 19 orang siswa memperoleh nilai 60-72, 17 orang siswa memperoleh nilai 73-90. Dari data ini diketahui bahwa dari 4 kelas $\mathrm{XI}$, yang berjumlah 141 siswa hanya 50 orang siswa yang memenuhi KKM dan 91 orang siswa tidak memenuhi KKM. Sebaran nilai ini menunjukan adanya proses pembelajaran yang masih belum optimal. Kondisi ini juga diakibatkan karena kurangnya kerjasama antara guru dengan siswa dan sesama siswa satu dan yang lainnya, hal inilah yang menyebabkan pembelajaran kurang optimal.

Menurut (Ibrahim, 2000: 25). Model pembelajaran Kooperatif tipe TPS 
adalah pembelajaran yang memberi siswa kesempatan untuk bekerja sendiri dan bekerja sama dengan orang lain. TPS memiliki prosedur secara eksplisit dapat memberi siswa waktu lebih banyak untuk berpikir, menjawab, saling membantu satu sama lain. "Struktur model pembelajaran kooperatif tipe TPS ini menghendaki siswa bekerja saling membantu dalam kelompok kecil (2-6 anggota) dan lebih dicirikan oleh penghargaan kooperatif dari pada penghargaan individu." Model pembelajaran kooperatif tipe TPS diawali dengan pertanyaan dari guru mengenai suatu masalah dari guru. Kemudiam siswa akan diajak untuk memecahkan masalah tersebut dengan diskusi bersama kelompoknya. Hasil diskusi akan dibagikan kepada kelompok lain. Melalui model pembelajaran TPS siswa diajak untuk untuk berpikir, merespon, serta saling bantu atau bekerja sama dengan siswa lain.

Penerapan model pembelajaran kooperatif tipe TPS diharapkan dapat mengatasi permasalahan-permasalahan yang terdapat di Kelas XI sehingga dapat meningkatkan hasil belajar siswa.

\section{KAJIAN TEORI}

Pelaksanaan

pembelajaran penjasorkes dengan aktivitas gerak sebagai sarana pencapaian tujuan harus selalu direncanakan dengan baik oleh guru penjasorkes penyampaian informasi pada bagian awal pengajaran penjasorkes sangat berpengaruh terhadap pencapaian tujuan pengajaran. Penyampaian informasi itu memiliki dua macam tujuan, yaitu agar siswa mengetahui dan memahami apa yang dikerjakan, dan memahami bagaimana cara melakukannya.

Pendidikan jasmani, olahraga dan kesehatan (Penjasorkes) merupakan bagian integral dari pendidikan secara keseluruhan, dimana bertujuan untuk mengembangkan aspek kebugaran jasmani, keterampilan gerak, keterampilan berpikir kritis, keterampilan sosial, penalaran stabilitas emosional, tindakan moral, aspek pola hidup sehat dan pengenalan lingkungan bersih melalui aktivitas jasmani, olahraga dan kesehatan terpilih yang direncanakan secara sistematis dalam rangka mencapai tujuan pendidikan nasional (Depdiknas, 2006:163).

Menurut Joyce (dalam Trianto, 2007:5) model pembelajaran adalah suatu perencanaan atau suatu pola yang digunakan sebagai pedoman dalam merencanakan pembelajaran di kelas untuk menentukan perangkat-perangkat pembelajaran termasuk di dalamnya buku-buku, film, komputer, kurikulum, dan lain-lain. Adapun model pembelajaran yang dapat diterapkan dalam pembelajaran (Suprijono, 2009:46-68) sebagai berikut: a) model pembelajaran langsung, b) model pembelajaran kooperatif, dan c) model pembelajaran berbasis masalah.

Dalam pembelajaran kooperatif siswa tetap tinggal dalam kelompoknya selama beberapa kali pertemuan. Mereka diajarkan keterampilan-keterampilan khusus agar dapat bekerja sama dengan baik didalam kelompoknya, seperti menjadi pendengar aktif, memberi penjelasan teman kelompok dengan baik, dan dapat melakukan diskusi kelompok. Pembelajaran belum selesai jika salah satu anggota kelompok ada yang belum menguasai materi pelajaran.

Menurut Trianto (2007:42), pembelajaran kooperatif bertujuan untuk: "(1) meningkatkan partisipasi siswa, (2) memfasilitasi siswa dengan pengalaman sikap kepemimpinan dan membuat keputusan dalam kelompok, dan (3) memberikan kesempatan kepada siswa untuk berinteraksi dan belajar bersamasama siswa yang berbeda latar belakangnya". Jadi, model pembelajaran kooperatif merupakan model yang mengkondisikan siswa bekerja bersama untuk memperoleh tujuan bersama dalam kelompok-kelompok kecil dengan tingkat kemampuan yang berbeda-beda.

Menurut Ibrahim dkk (2000:11), "pembelajaran kooperatif akan menjadi sangat efektif jika materi pembelajaran tersedia lengkap di kelas, ruang guru, perpustakaan, ataupun dipusat media".

Terdapat lima unsur dasar dalam pembelajaran kooperatif (Santyasa, 
2005:89-96) yaitu: “a) saling ketergantungan positif, b) interaksi tatap muka, c) keterampilan-keterampilan kolaboratif, d) pemrosesan interaksiinteraksi kelompok, e) tanggung jawab individu".

"Model pembelajaran TPS didasarkan pada pembelajaran kooperatif diharapkan dapat memberikan siswa waktu lebih banyak untuk berpikir, mengemukakan pendapat dan saling membantu satu sama lain" (Ibrahim, 2000: 26). Model pembelajaran TPS sangat cocok diterapkan dikelas yang memiliki kemampuan akademik yang heterogen, kerjasama siswa rendah, serta kurang aktifnya siswa dalam hal mengungkapkan argumentasinya.

Menurut Trianto (2007: 61-62) adapun langkah-langkah dari model pembelajaran TPS yaitu “(a) thinking (berpikir), (b) pairing (berpasangan) dan (c) sharing (berbagi)".

Langkah 1 : Berpikir (Thinking)

Guru mengajukan suatu pertanyaan atau masalah yang dikaitkan dengan pelajaran, dan meminta siswa menggunakan waktu beberapa menit untuk berpikir sendiri jawaban atau masalah. Siswa membutuhkan penjelasan bahwa berbicara atau mengerjakan bukan bagian berpikir.

Langkah 2 : Berpasangan (Pairing)

Selanjutnya guru meminta siswa untuk berpasangan dan mendiskusikan apa yang telah mereka peroleh. Interaksi selama waktu yang desediakan dapat menyatukan jawaban jika suatu pertanyaan yang diajukan atau menyatukan gagasan apabila suatu masalah khusus yang diidentifikasi.

Langkah 3 : Berbagi (Sharing)

Pada langkah akhir, guru meminta pasangan-pasangan untuk berbagi dengan keseluruhan kelas yang telah mereka bicarakan. Setiap model pembelajaran mempunyai ciri tersendiri dan mumpunyai keunggulan serta kelemahan. Demikian halnya dengan model pembelajaran kooperatif tipe TPS mempunyai keuntungan dan kelemahan seperti yang diungkapkan oleh Suryosubroto (dalam Trianto, 2007: 127128), yaitu:
1. Keuntungan TPS

Keunggulan yang terdapat dalam model pembelajaran kooperatif tipe TPS yaitu sebagi berikut.

a. Melibatkan semua siswa secara langsung dalam kegiatan belajar mengajar.

b. Setiap siswa dapat menguji tingkat pengetahuan dan penguasaan bahan pembelajaran masing-masing.

c. Diskusi dapat menumbuhkan dan mengembangkan cara berfikir dan sikap ilmiah.

d. Dengan mengajukan dan mempertahankan pendapatannya dalam diskusi diharapkan para siswa akan dapat memperoleh kepercayaan akan (kemampuan) diri sendiri.

e. Diskusi dapat menunjang usaha-usaha pengembangan sikap sosial dan sikap demokratis para siswa.

2. Kelemahan TPS

Selain keunggulan, model pembelajaran tipe TPS juga mempunyai kelemahan yaitu sebagai berikut.

a. Dapat diramalkan sebelumnya mengenai bagaimana hasilnya sebab tergantung kepada kepemimpinan dan partisipasi anggota-anggotanya.

b. Memerlukan keterampilan-keterampilan tertentu yang belum pernah dipelajarinya.

c. Dapat dikuasai (didominasi) oleh beberapa siswa yan menonjol.

d. Memerlukan waktu yang banyak.

e. Sulit untuk membatasi pengungkapan pendapat siswa.

f. Jumlah siswa yang banyak sulit untuk memberikan waktu dalam mengungkapkan pendapatnya.

Pembelajaran konvensional menekankan pada guru sebagai pusat informasi dan siswa sebagai penerima informasi. Situasi kelas sebagian besar masih berfokus pada guru sebagai sumber utama pengetahuan, serta pengguanaan model ceramah sebagai pilihan utama strategi belajar mengajar. Model pembelajaran konvensional adalah model pembelajaran tradisional atau disebut juga model ceramah, karena sejak dulu model ini telah dipergunakan sebagai alat komunikasi lisan antara guru dengan anak didik dalam proses belajar mengajar. Model pembelajaran konvensional memiliki beberapa jenis metode yang 
dapat diterapkan dalam proses pembelajaran diantaranya adalah metode ceramah, metode demonstrasi, dan metode penugasan. Salah satu metode pembelajaran yang diterapkan adalah metode ceramah.

Menurut Suryosubroto (2009: 155) metode ceramah merupakan penuturan materi pembelajaran yang dilakukan oleh guru secara lisan baik dengan media atau tidak, tugas guru adalah memberikan ilmu sedangkan siswa sebagai penerima. Ketika menjelaskan materi pembelajaran siswa memerhatikan dan mencatat materi yang disampaikan oleh guru. Pusat proses pembelajaran menggunakan metode ceramah adalah guru (teacher center).

Menurut Dimyati dan Mudjiono (2006:3), "dengan berakhirnya suatu proses belajar, maka siswa memperoleh suatu hasil belajar. Hasil belajar merupakan hasil dari suatu interaksi tindak belajar dan tindak mengajar". "Hasil belajar tersebut dapat dibedakan menjadi dampak pengajaran dan dampak pengiring. Dampak pengajaran adalah hasil yang dapat diukur dengan segera atau secara langsung. Sedangkan dampak pengiring adalah hasil belajar siswa yang tampak secara tidak langsung atau merupakan transfer hasil belajar" (Dimyati dan Mudjiono, 2006:295). "Hasil belajar adalah kemampuan-kemampuan yang dimiliki siswa setelah menerima pengalaman belajarnya" (Sudjana, 2004:22). Hasil belajar digunakan oleh guru untuk dijadikan ukuran atau kriteria dalam mencapai suatu tujuan pendidikan.

Dimyati dan Mudjiono (2006:26), "siswa yang belajar berarti menggunakan kemampuan kognitif, afektif dan psikomotor untuk berinteraksi terhadap lingkungannya dalam melakukan kegiatan belajar". Berdasarkan uraian di atas di dalam instruksional, Bloom, dkk (dalam Dimyati dan Mudjiono, 2006:26) "mengkatagorikan jenis perilaku dan kemampuan internal akibat belajar, antara lain: a) ranah kognitif, b) ranah afektif, dan c) ranah psikomotor".

"Permainan sepakbola dimainkan oleh dua tim yang masing-masing beranggotakan 11 orang. Masing-masing tim mempertahankan sebuah gawang dan mencoba menjebolkan ke gawang lawan" PSSI (dalam Satyawan, 2012:2). Setiap tim memiliki kiper yang mempunyai tugas untuk menjaga gawang. Kiper diperbolehkan untuk mengontrol bola dengan tangannya di dalam daerah penalti. Pemain lainnya tidak diperbolehkan menggunakan tangan atau lengan mereka untuk mengontrol bola, tetapi mereka dapat menggunakan kaki, tungkai, atau kepala. Gol diciptakan dengan menendang atau menanduk bola ke dalam gawang lawan. Setiap gol dihitung dengan skor satu, dan tim yang paling banyak menciptakan gol memenangkan permainan.

PSSI (dalam Satyawan 2012:6) menyatakan, Lapangan sepakbola dibuat di lapangan tanah berbentuk segi empat yang tertutup dengan rumput pendek dan rapat. Untuk permainan penuh, lapangan sepak bola berukuran panjang sekitar 100-110 m dan lebar 64-75 m. Garis-garis batas harus jelas, biasanya garis ini dibuat menggunakan lumpur atau cat putih dengan lebar $12 \mathrm{~cm}$. Di sekeliling lapangan, $4 \mathrm{~m}$ dari garis putih tidak diperkenankan untuk penonton.

Adapun teknik dasar permainan sepakbola menurut Mielke (2007:1) adalah sebagai berikut: "1) menggiring bola (dribbling), 2) mengoper (passing), 3) menghentikan bola (trapping), 4) lemparan ke dalam (throw-in), 5) menyundul bola (heading), 6) mengecoh dan membalik (tricks and turns), 7) menembak (shooting)".

\section{METODE PENELITIAN}

Jenis penelitian yang digunakan dalam penelitian ini adalah eksperimen sesungguhnya (true experimental). Rancangan penelitian menggunakanthe randomized pretest-posttest control group the same subjec design (Kanca, 2010:87).

Dalam penelitian ini yang menjadi subjek penelitian adalah siswa Kelas XI SMA Saraswati Seririt tahun pelajaran 2017/2018 yang terdistribusi kedalam 2 kelas yaitu: Xi IPA berjumlah 34 orang dan XI IPS 1 berjumlah 36 orang, sehingga keseluruhan jumlah subjek 
penelitian adalah 70 orang. Dua kelas yang ada diundi untuk menetapkan kelas yang menjadi kelas eksperimen dan kelas kontrol.

Pengambilan data hasil belajar dilakukan dengan cara memberikan tes objektif, observasi, dan unjuk kerja. Analisis data dilakukan dengan menggunakan Uji-t.Sebelum dilakukan ujit terlebih dahulu data diuji normalitas dan homogenitasnya.

\section{HASIL dan PEMBAHASAN}

Data tentang hasil belajar teknik dasar passing dan control sepakbola diperoleh melalui tes untuk kelompok eksperimen dan kelompok control.Data hasil belajar teknik dasar passing dan control sepakbola diperoleh melalui data GSn (Gain Score yang ternormalisasi). Dari hasil pada kedua kelompok diperoleh rata-rata nilai siswa kelas XI IPA (kelompok eksperimen) adalah 0.509, varians 0.14 , dan simpangan baku 0.1192 . Sedangkan rata-rata nilai siswa kelas XI IPS 1 (kelompok kontrol) adalah 0.286 , varians 0.14 , dan simpangan baku 0.1195.Yang ditunjukan pada tabel 01 .

Tabel 01

Rangkuman Hasil Analisis Data Hasil Belajar Teknik Dasar Passing Sepak Bola

\begin{tabular}{lrrrrrrr}
\hline & \multicolumn{4}{c}{ Tests of Normality } & & & \\
& \multicolumn{3}{c}{ Kolmogorov-Smirnova } & \multicolumn{3}{c}{ Shapiro-Wilk } \\
gn & $\begin{array}{l}\text { Kelas } \\
\text { XI IPA }\end{array}$ & Statistic & df & Sig. & Statistic & Df & Sig. \\
$\begin{array}{l}\text { Eksperimen } \\
\text { XI IPS 1 }\end{array}$ & .144 & 34 & .071 & .927 & 34 & .026 \\
Kontrol & .142 & 36 & .064 & .929 & 36 & .024 \\
\hline
\end{tabular}

didukung dengan gambar

Hasil diskriptif diatas juga

histogram disertai kurva normal untuk kelompok ekperimen ( kelas XI IPA) dan kelompok kontrol (kelas XI IPS) 

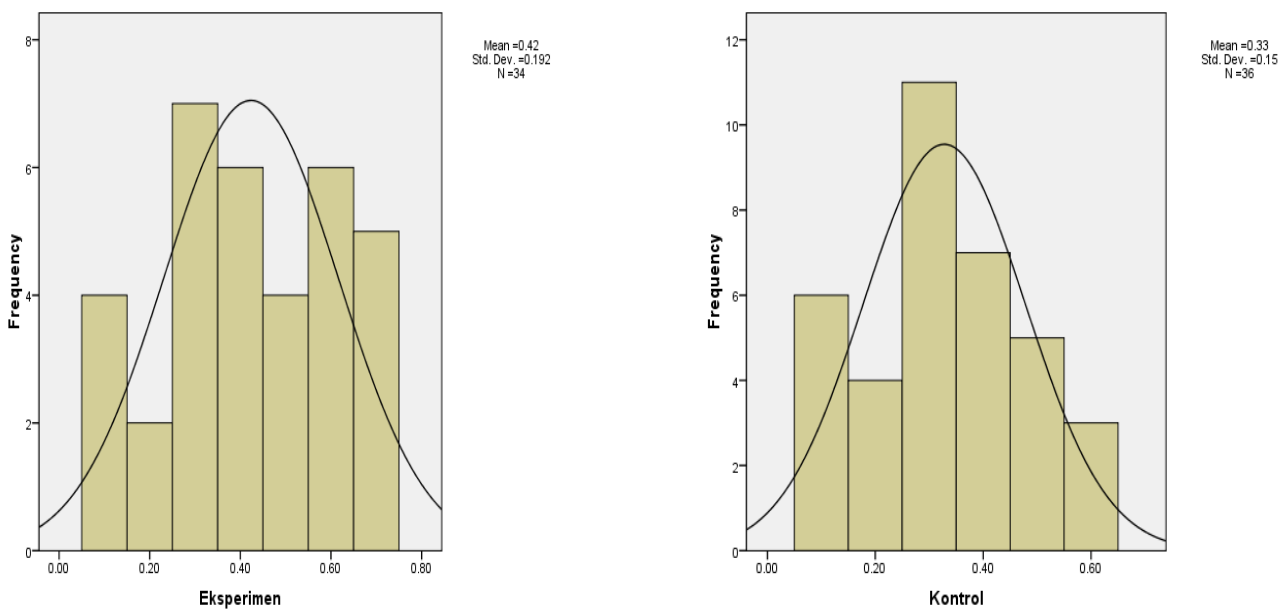

Gambar 01

Histogram Data N-Gain Score (Disertai Kurve Normal)

Dari gambar 01 diatas menunjukkan bahwa, histogram untuk $\mathrm{N}$-gain score $\mathrm{X}$ IPA memiliki distribusi "miring ke kanan (kiri bagi kita yang melihatnya) distibusi normal" karena nilai skewness negatif dan "melandai" karena nilai kurtois negatif.
Sedangkan histogram untuk $N$-gain score IPS 1 memiliki distribusi "miring ke kiri (kanan bagi kita yang melihatnya) distribusi normal" karena nilai skewness positif dan "melandai" karena nilai kurtois negatif.

Tabel 02

Hasil Uji Normalitas Sebaran Data

\begin{tabular}{|c|c|c|c|c|c|c|c|}
\hline \multirow{2}{*}{\multicolumn{8}{|c|}{$\begin{array}{l}\text { Tests of Normality } \\
\text { Kolmogorov-Smirnov }^{a}\end{array}$}} \\
\hline & & & & & & & \\
\hline \multirow{3}{*}{ gn } & Kelas & Statistic & $d f$ & Sig. & Statistic & $d f$ & Sig. \\
\hline & $\begin{array}{l}\text { XI IPA } \\
\text { Eksperimen }\end{array}$ & .144 & 34 & .071 & .927 & 34 & .026 \\
\hline & $\begin{array}{l}\text { XI IPS } 1 \\
\text { Kontrol }\end{array}$ & .142 & 36 & .064 & .929 & 36 & .024 \\
\hline \multicolumn{4}{|c|}{$\begin{array}{l}\text { Sebelum uji hipotesis terlebih } \\
\text { dilakukan pengujian prasyarat } \\
\text { ap sebaran data yang meliputi uji } \\
\text { litas sebaran data dan uji } \\
\text { yenitas varians. Untuk mengetahui } \\
\text { litas sebaran data digunakan rumus } \\
\text { gorov-Smirnov pada signifikansi }\end{array}$} & \multicolumn{4}{|c|}{$\begin{array}{l}\text { dilakukan dengan menggunakan SPSS } \\
16.00 \text { for Windows didapatkan hasil Nilai } \\
\text { sig untuk GSn kelas XI IPA dan kelas XI } \\
\text { IPS } 1 \text { adalah } 0.071 \text { dan } 0.064 \text { yaitu lebih } \\
\text { dari } 0.05 \text { sehingga data GSn kedua kelas } \\
\text { berasal dari populasi yang berdistribusi } \\
\text { normal. }\end{array}$} \\
\hline
\end{tabular}

0,05 . Berdasarkan analisis yang telah 
Tabel 03

Hasil Uji Homogenitas Varians dan Hasil Uji T

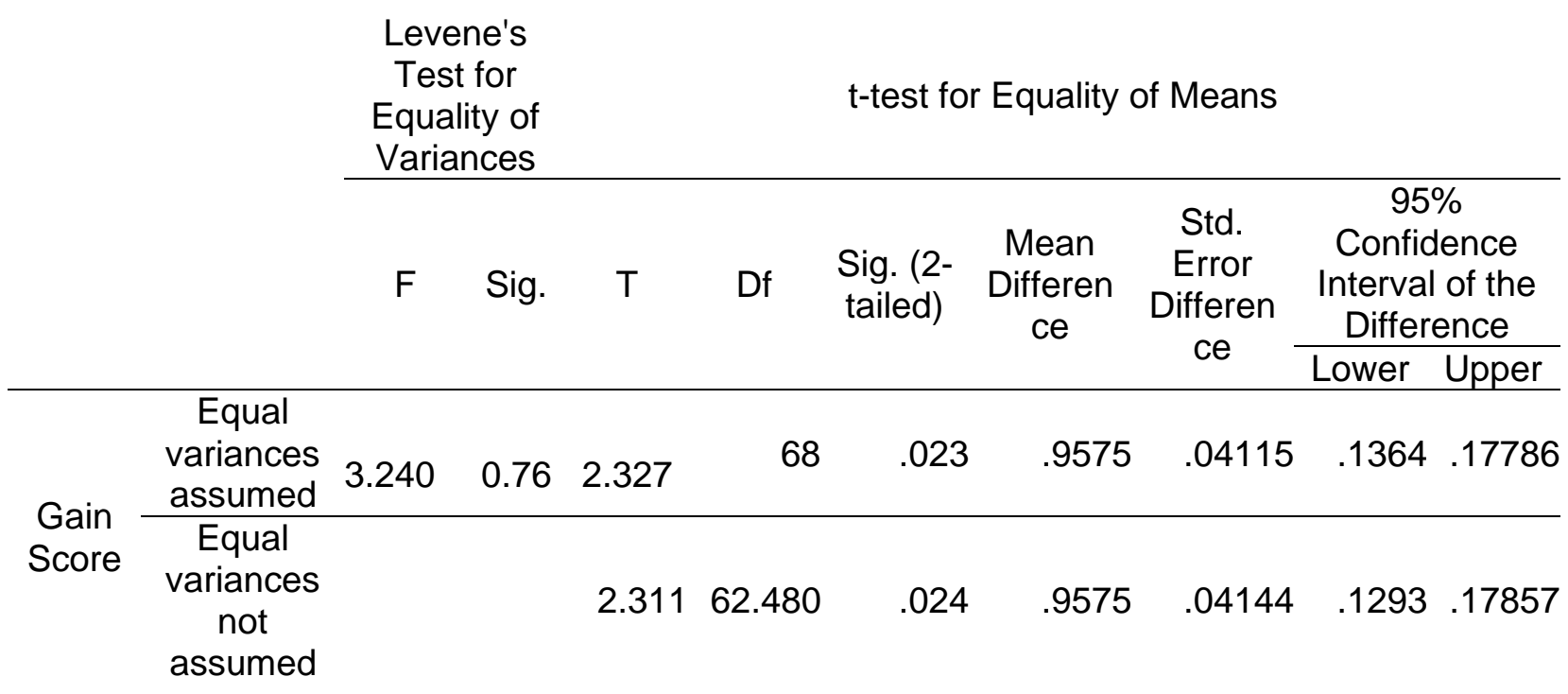

Berdasarkan hasil perhitungan homogenitas data menggunakan uji Levene's ditunjukkan bahwa untuk hasil belajar teknik dasar passing sepak bola siswa yaitu 0.076 yaitu lebih dari 0.05 sehingga tidak terdapat perbedaan varians kedua kelompok atau varians data GSn (gain skor ternormalisasi) kedua kelas homogen.

Untuk uji hipotesis penelitian digunakan uji t dua ekor dengan asumsi varians yang sama. Nilai sig pada kolom sig (2-tailed) dan baris equal variances assumed, jika nilai sig $<0.05$ artinya $\mathrm{Ho}$ ditolak dan $\mathrm{H} 1$ diterima. Nilai sig untuk uji hipotesis adalah 0.023 dan 0.0024 yaitu kurang dari 0.05 sehingga Ho ditolak dan $\mathrm{H} 1$ diterima.

Hasil ini menyatakan bahwa terdapat perbedaan hasil belajar teknik dasar passing sepak bola antara siswa yang diberi perlakuan menggunakan model pembelajaran kooperatif tipe TPS dengan siswa yang diberi perlakuan model pembelajaran konvensional. Berdasarkan angka rata-rata terlihat bahwa rata-rata peningkatan hasil belajar pada kelompok eksperimen lebih besar daripada kelompok kontrol. Dapat disimpulkan bahwa hasil belajar pada siswa yang dibelajarkan menggunakan model pembelajaran kooperatif tipe TPS lebih tinggi daripada siswa yang dibelajarkan menggunakan model pembelajaran konvensional.

Penelitian ini bertujuan meningkatkan aktivitas dan hasil belajar passing sepakbola melalui implementasi model pembelajaran kooperatif tipe TPS pada siswa kelas $X 7$ SMA Negeri 1 Susut tahun pelajaran 2013/2014. Penelitian ini adalah Penelitian Tindakan Kelas yang dilaksanakan dalam dua siklus. Subjek penelitian siswa kelas $X 7$ SMA Negeri 1 Susut, berjumlah 38 orang. Data menggunakan analisis statistik deskriptif. Hasil analisis data pada observasi awal aktivitas belajar passing sepakbola secara klasikal sebesar 5, 66 (cukup aktif) meningkat pada siklus I menjadi 7, 21 (Aktif) dan siklus II menikat sebesar 9, 1 (Aktif). Sedangkan ketuntasan hasil belajar passing sepakbola secara klasikal pada observasi awal 61, 48 (Kurang Baik), siklus I meningkat sebesar 71, 41 (Cukup Baik), pada siklus II meningkat sebesar 81, 31 (Baik). Berdasarkan analisis data disimpulkan bahwa aktivitas dan hasil belajar.

\section{SIMPULAN}


Berdasarkan hasil analisis data dan pembahasan dapat disimpulkan bahwa penerapan model pembelajaran kooperatif tipe TPS berpengaruh sangat signifikan terhadap peningkatan hasil belajar passing dan control sepakbola (kaki bagian dalam) pada siswa kelas XI SMA Saraswati Seririt tahun pelajaran 2017/2018.

Berdasarkan hasil analisis data, pembahasan, dan kesimpulan maka dapat diajukan beberapa saran untuk proses pembelajaran dan penelitian lebih lanjut sebagai berikut. 1) Bagi guru Penjasorkes, model pembelajaran kooperatif tipe TPS dapat dijadikan salah satu alternatif pembelajaran yang dapat diterapkan di kelas. 2) Penelitian ini dilaksanakan pada pokok bahasan teknik dasar passing dan control sepakbola (kaki bagian dalam) sehingga untuk memperoleh bukti-bukti yang lebih umum dari penerapan model pembelajaran kooperatif tipe TPS diharapkan peneliti lain untuk mencoba pada pokok bahasan lain untuk mengetahui pengaruh penerapan model pembelajaran kooperatif tipe TPS dalam pembelajaran Penjasorkes secara lebih mendalam. 3) Penelitian ini hanya mengukur ada atau tidaknya pengaruh dari model pembelajaran kooperatif tipe TPS terhadap hasil belajar teknik dasar passing dan cotrol sepakbola kaki bagian dalam) tanpa meneliti lebih jauh arah pengaruh yang diberikan. $\mathrm{Di}$ waktu mendatang dapat dilakukan suatu penelitian untuk meneliti sejauh mana arah pengaruh yang diberikan oleh model pembelajaran kooperatif tipe TPS terhadap hasil belajar Penjasorkes siswa.

\section{DAFTAR RUJUKAN}

Budiantara, I. K., Artanayasa, I. W., \& Satyawan, I. M. 2014.

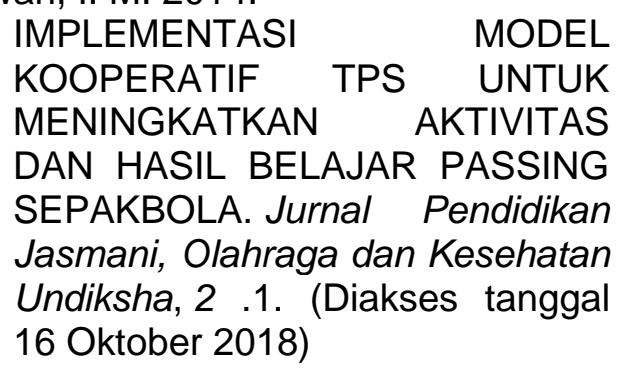

Desain Eksperimen Dan Analisis

Data. Depok : PT Raja

Grafindo Persada

Dimiyati dan Mudjiono. 2006. Belajardan

Pembelajaran. Jakarta: Rineka Cipta.

Mielke, Dany. 2007. Dasar-Dasar Sepak Bola. Bandung: Pakar Raya.

Ibrahim, Rachmadiarti, dkk. 2000.

Pembelajaran Kooperatif.

Surabaya: Unesa-university press.

Satyawan. 2012. Buku Ajar Permainan Sepak Bola. Jurusan

Pendidikan Jasmani Kesehatan

dan Rekreasi, Fakultas

Olahraga dan Kesehatan,

Universitas Pendidikan

Ganesha Singaraja.

Subadi, Tjipto. 2011. Inovasi Pendidikan.

Surakarta: Muhammadiyyah

University Press

Suprijono, Agus. 2009. Cooperative Learning. Surabaya: Pustaka Belajar.

Kanca, I Nyoman.2010.

Metode Penelitian Pengajaran Pendidikan Jasmani dan Olahraga. Singaraja: UniversitasPendidikan Ganesha. 